\title{
Fungal Pectinase Production Optimization and its Application in Buffaloe's Diets Degradation
}

\author{
El Garhy GM1, Azzaz HH², Abd El Mola AM1 and Mousa GA1* \\ ${ }^{1}$ Department of Animal Production, Faculty of Agriculture, Fayoum University, Egypt \\ ${ }^{2}$ Department of Dairy sciences, National Research Centre, Egypt
}

*Corresponding author: Gamal Ahmed Moussa, Department of Animal Production, Faculty of Agriculture, Fayoum University, Egypt, Tel: +201115963289; Email: gam02@fayoum.edu.eg

\section{Research Article \\ Volume 3 Issue 1}

Received Date: December 09, 2019

Published Date: January 17, 2020

DOI: $10.23880 /$ izab-16000199

\section{Abstract}

Pectinase production for improving buffalo's diets digestion is the main objective of this work. Effects of fungal strains and different cultivation conditions on pectinase production have been studied. In vitro batch culture technique was used for investigate impact of the produced pectinase compared with commercial pectinase (SMIZYME ${ }^{\circledR}$ ) on rumen fermentation parameters and diet degradation. Penicillium chrysogenum exhibited the highest pectinase activity at 3 days of incubation period, initial pH 4 of the growth medium, yeast extract as a sole nitrogen source and pomegranate peel as a carbon source at a concentration of $15 \%(\mathrm{~W} / \mathrm{V})$. Three $(\mathrm{g} / \mathrm{kg})$ of the both enzymes supplementation significantly increased treated diet's dry matter (DM), neutral detergent fiber (NDF), acid detergent fiber (ADF) degradability with increase total gas production (TGP) and short chain fatty acids (SCFA) concentration. The enlargement of pectinase production locally will lead to animal production improvement, encourage self-reliance and reduce the cost of enzymes importation.

Keywords: Pectinase Production; Penicillium Chrysogenum; Pomegranate Peel; Rumen Microorganisms and Buffaloes' Diets

Abbreviations: DM: Dry Matter; NDF: Neutral Detergent Fiber; ADF: Acid Detergent Fiber; TGP: Total Gas Production; SCFA: Short Chain Fatty Acids; PDA: Potato Dextrose Agar; PPPM: Pomegranate Peel Powder Medium; CMC: Carboxymethyl-Cellulase; BPPM: Beet Pulp Powder Medium; TMR: Total Mixed Ration; VFA: Volatile Fatty Acids.

\section{Introduction}

Pectinase is a generic name group of enzymes that catalyze break down of the glycosidic bonds of the galacturonic acid long chain residues in the pectin rich plants [1]. Pectinases make up almost $25 \%$ of the global food enzyme market because of its wide range of applications in food, feed and pharmaceutical industries 
[2]. It is expected that value of food enzymes market will increase up to $\$ 41.4$ billion by 2020 , with a compounded annual growth rate of $6.7 \%$ [3]. The major constraint for commercialization of new sources of enzymes is higher cost of the production [4]. It is thought that define the optimal microbial cultivation conditions for capable microbial strains and cheap raw substrate may reduce the cost of enzymes production [5]. A large number of bacteria, yeasts and many filamentous fungi are potential pectinase producers [6]. Fungi (ex: T. viride, A. flavus, $A$. niger, $F$. oxysporum, $A$. terreus, and $P$. chrysogenum) have attracted the most attention as enzymes producers because of its prolific yield and its long history in fermentation industries [1,5,7-9]. Submerged fermentation technique is still the most favorable system for microbial enzymes production in large-scale, despite a lot of research papers recommended solid state fermentation for microbial enzymes (ex: pectinase) production [1,7]. Utilization of agricultural residues as carbon sources in pectinase production media has yielded good enzyme activity with reduction of the production cost $[6,7]$.

Utilization of microbial pectinases in agriculture waste treatments or as livestock feed supplements was expanded in the last two decades [6]. Many studies reported good impact of pectinase as a fibrolytic enzyme on ruminant's diets degradation in vitro and in vivo $[4,10$ 12]. Addition of pectinase to ruminant's feeds can reduces the feed viscosity, which increases absorption of nutrients, liberates nutrients, either by hydrolysis of nonbiodegradable fibers or by liberating nutrients blocked by these fibers, and reduces the amount of feces [7]. It is well known that pectin constitute the main component of cell wall of orange peel, sugar beet pulp, and pomegranate peel, that become essential source for livestock feeding in Egypt. Therefore, this study was carried out to optimize production of fungal pectinase, and evaluates impact of the produced pectinase for improving degradation of buffaloe's diets rich in pectin.

\section{Material and Methods}

\section{Fungi and Inoculum Preparation}

Fusarium avenaceum, Asperigillus fugimatus, Cephalosporium acremonium, Trichoderma viride, Aspergillus niger, Fusarium oxysporum, Aspergillus terreus, and Penicillium chrysogenum were obtained from Dairy Microbiology LAB - National Research Centre, Giza, Egypt. These fungi were cultivated and maintained on potato dextrose agar medium (PDA). Malt medium containing malt extract $(30 \mathrm{~g} / \mathrm{l})$; yeast extract $(5 \mathrm{~g} / \mathrm{l})$ was used for preparing the activated fungal inocula; beet pulp powder medium (BPPM) was used for growth and pectinase production. The medium has the following composition (g/l) NaCl, 6.0; $\left(\mathrm{NH}_{4}\right)_{2} \mathrm{SO}_{4}, 1.0 ; \mathrm{K}_{2} \mathrm{HPO}_{4}, 1.0 ; \mathrm{MgSO}_{4}, 7 \mathrm{H}_{2} \mathrm{O}$, $0.05 ; \mathrm{CaCl}_{2}, 0.1$; yeast extract, 0.5 ; peptone, 0.5 ; glucose, 4.0; beet pulp powder, 10.0 and medium $\mathrm{pH}$ was adjusted to $\mathrm{pH}$ 6.0. Spores of fungi were transferred from surface of the actively growing slants of (PDA) medium to $250 \mathrm{ml}$ conical flasks each containing $50 \mathrm{ml}$ of malt medium. After incubation on a rotary shaker $(120 \mathrm{rpm})$ at $29^{+} 1^{\circ} \mathrm{C}$ for 48 $\mathrm{h}$, the grown culture was employed as inocula for experimental $1000 \mathrm{ml}$ conical flasks containing $100 \mathrm{ml}$ (BPPM) at rate of $5 \%(\mathrm{~V} / \mathrm{V})$ inoculum size.

\section{Culture Conditions Affecting Pectinase Production}

Static cultures were used for studying pectinase production by Penicillium chrysogenum under variable condition including substrate (pomegranate peel) concentration effect, incubation period, initial $\mathrm{pH}$ and nitrogen source. The general procedure included use of triplicate of $1000 \mathrm{ml}$ conical flasks each containing $100 \mathrm{ml}$ of pomegranate peel powder medium ( PPPM).

Effect of different substrate sources includes pea pods, pomegranate peel, sugar beet pulp and orange peel on pectinase production by Penicillium chrysogenum was investigated.

Effect of substrate (pomegranate peel) concentration ranged from $2.5 \%$ to $20 \%(\mathrm{~W} / \mathrm{V})$ on pectinase production by Penicillium chrysogenum was investigated. The fermented pomegranate peel for each flask was mixed with $100 \mathrm{ml}$ of $0.02 \mathrm{M}$ acetate buffer ( $\mathrm{pH} 5.0$ ) by shaking in a rotary shaker $(120 \mathrm{rpm})$ for one hour at room temperature to extract the enzyme and the extracted mixture was filtered and collected for pectinase activity assay.

The influence of incubation period was studied through determination of pectinase activities after 24,48 , $72,96,120,144$ and $168 \mathrm{~h}$. Effect of the initial $\mathrm{pH}$ of growth medium was studied through adjusting the initial $\mathrm{pH}$ values in a range between 3 and 8 using either $0.1 \mathrm{~N}$ $\mathrm{NaOH}$ or $\mathrm{HCl}$.

Effect of nitrogen source included the use of two inorganic salts (ammonium sulphate, and ammonium chloride; and three organic sources (Peptone, yeast extract and urea) were studied. Various nitrogen sources were used separately at an equivalent concentration of $0.33 \mathrm{~g} \mathrm{~N} / \mathrm{l}$ media as recommended by Murad, et al. These 
nitrogen sources replaced the original nitrogen source present in the PPPM. The level of a parameter optimized in an experiment was maintained in the subsequent studies.

\section{Enzymes Sources}

The produced enzyme: Laboratory produced fibrolytic enzymes from Penicillium chrysogenum. Each gram contains 200 units of pectinase and 98.82 unit of cellulase. It worth to mention that, the pectinase units of each gram of the produced enzyme was adjusted to be equivalent to that found in the commercial enzyme product (SMIZYME ${ }^{\circledR}$ ).

SMIZYME: A commercial enzymes source from AGRI-VET Company, Egypt. Each gram contains 200 unit of pectinase, 100 unit of cellulase, 2500 unit of $\alpha$-amylase, 10000 unit of protease, 5000 unit of xylanase, 300 unit of mannanase, and 3000 unit of beta-glucannase.

Enzymes assay: The pectinase and carboxymethylcellulase activities (CMC) for resultant crude enzyme extract (the produced enzyme) and commercial enzyme source (SMIZYME ${ }^{\circledR}$ ) were determined according to Buga, et al. [13] Mandels, et al. [14] respectively. One unit of pectinase activity was defined as the amount of enzyme that produced one $\mu$ mole of D-galacturonic acid per minute at $40^{\circ} \mathrm{C}$ and $\mathrm{pH} 5.0$ [15], while one cellulase unit was defined as the amount of enzyme that liberates reducing sugar at the rate of one $\mu \mathrm{mol} / \mathrm{ml} / \mathrm{min}$ under assay condition [16].

In vitro trial of the tested rations: Batch fermentation culture experiment was conducted according to Ismail, et al. [17] to evaluate impact of the produced and commercial fibrolytic enzymes sources addition to ruminant's diets on rumen fermentation characteristics. A total mixed ration consisted of of $50 \%$ concentrates feed mixture, 20\% Egyptian clover, $20 \%$ Sugar beet pulp and $10 \%$ dried orange pulp was used as a substrate. The concentrate feed mixture consisted of 55\% corn, $20 \%$ soybean meal, $21.5 \%$ wheat bran, $1.5 \%$ limestone, $0.5 \%$ di calcium phosphate, $0.2 \%$ yeast, $0.3 \%$ bicarbonate, 0.5 $\%$ premix and $0.5 \% \mathrm{NaCl}$. For obtaining of the rumen microorganisms (inoculum), rumen fluid was collected from rumen of slaughtered rams fed clover hay ration. The produced and the commercial fibrolytic enzymes were added to control ration at the following levels: 0,1 , 2, 3, 4 and $5 \mathrm{~g} / \mathrm{kg}$ on DM basis. Each treatment was tested in 3 replicates accompanied by 3 blank vessels (no substrate). The tested rations (400 mg) were added separately to the $125 \mathrm{ml}$ incubation vessels. Each vessel was filled with $40 \mathrm{ml}$ of mixture of $1: 3(\mathrm{v} / \mathrm{v})$ rumen fluids: buffer solution. All vessels were sealed and incubated at $39^{\circ} \mathrm{C}$ for $24 \mathrm{~h}$. After $24 \mathrm{~h}$ of incubation, all vessels were filtered in fiber filter bags 25 micron porosity (ANKOMUSA). The residues in the bags were dried at $70^{\circ} \mathrm{C}$ in oven for $48 \mathrm{~h}$ to analyse dry matter (DM), neutral detergent fiber (NDF) and acid detergent fiber (ADF) digestibility. Rumen fluid $\mathrm{pH}$ was measured using ( $\mathrm{pH}$-meter). Overall volume of the produced gases was determined using Hohenheim Syringes $(100 \mathrm{ml})$ as described by NavarroVilla, et al. [18]. Quantitative analysis of ammonia concentration was carried out by a modified Nessler's method [19]. The short chain fatty acids (SCFA) concentration was calculated according to equation of Makkar, et al. [20].

$$
\text { SCFA }(\mathrm{mmol})=0.0222 \text { Gas }-0.00425
$$

Where, Gas: is gas production at 24 hours incubation (ml/200 mg DM).

\section{Statistical Analysis}

Statistical analyses were conducted by the general linear model procedure adapted by IBM Corp [21]. Released according to the following model:

$$
\mathrm{Y}_{\mathrm{ij}}=\mu+\mathrm{T}_{\mathrm{i}}+\mathrm{e}_{\mathrm{ij}}
$$

Where $Y_{i j}$, is the dependent variable, $\mu$ is the overall mean, $\mathrm{T}_{\mathrm{i}}$, is the effect of treatment and $\mathrm{e}_{\mathrm{ij}}$, is the residual error. Duncan's multiple test Duncan, et al. [22] was carried out to separate among means.

\section{Results and Discussion}

\section{Impact of Fungal Cultures on Pectinase Production}

The capability of Fusarium avenaceum, Trichoderma viride, Asperigillus flavus NRRL 5522, Cephalosporium acremonium, Fusarium oxysporum, Aspergillus niger, Asperigillus fugimatus, Penicillium chrysogenum and Aspergillus terreus on pectinase production on beet pulp powder medium (BPPM) was shown in Table 1. Penicillium chrysogenum gave significantly $(\mathrm{P}<0.05)$ the highest pectinase activity $(10.87 \mu \mathrm{mole} / \mathrm{ml} / \mathrm{min})$ followed by Aspergillus terreus $(9.37 \mu \mathrm{mole} / \mathrm{ml} / \mathrm{min})$ while the other fungal cultures gave low activity especially Fusarium avenaceum which gave the lowest pectinase activity $(8.09 \mu \mathrm{mole} / \mathrm{ml} / \mathrm{min})$. Pectinases produce by many of microorganisms including fungi, yeasts and bacteria [23-25]. However, almost all the commercial preparations of pectinases are produced from fungal sources [26,27]. Pectinase production by filamentous fungi varies according to the type of strain, cultivation conditions and the growth medium composition [1]. On 
the light of these results, Penicillium chrysogenum was chosen for further studies for pectinase production.

Table 1: Effect of fungal cultures on the produced pectinase activity $(\mu \mathrm{mole} / \mathrm{ml} / \mathrm{min})$.

\begin{tabular}{|c|c|c|}
\hline Fungal cultures & Pectinase activity ( $\mathbf{m m o l e} / \mathbf{m l} / \mathbf{m i n})$ & $\mathbf{\pm S E}$ \\
\hline Trichoderma viride & $8.24^{\mathrm{d}}$ & 0.05 \\
\hline Asperigillus flavus NRRL 5522 & $8.54^{\mathrm{cd}}$ & 0.08 \\
\hline Aspergillus niger & $8.77^{\mathrm{c}}$ & 0.28 \\
\hline Fusarium oxysporum & $8.86^{\mathrm{c}}$ & 0.13 \\
\hline Aspergillus terreus & $9.37^{\mathrm{b}}$ & 0.08 \\
\hline Penicillium chrysogenum & $10.87^{\mathrm{a}}$ & 0.12 \\
\hline Fusarium avenaceum & $8.09^{\mathrm{d}}$ & 0.15 \\
\hline Cephalosporium acremonium & $8.19^{\mathrm{d}}$ & 0.09 \\
\hline Asperigillus fugimatus & $8.12^{\mathrm{d}}$ & 0.06 \\
\hline
\end{tabular}

Average in the same column having different superscripts are differ significantly $(\mathrm{P}<0.05)$ for $a, b, c$ and $d$.

Table 2: Effect of different carbon sources, $\mathrm{pH}$ value, concentration of pomegranate peel, incubation period and nitrogen sources on produced pectinase enzyme $(\mu \mathrm{mole} / \mathrm{ml} / \mathrm{min})$ from Penicillium chrysogenum.

\begin{tabular}{|c|c|c|c|c|c|c|c|c|}
\hline \multicolumn{8}{|c|}{ Different carbon sources } & $\pm \mathrm{SE}$ \\
\hline \multirow{2}{*}{\multicolumn{2}{|c|}{$\begin{array}{c}\text { Pea pods } \\
8.79^{c}\end{array}$}} & \multirow{2}{*}{\multicolumn{2}{|c|}{$\frac{\text { pomegranate peel }}{10.53^{\mathrm{a}}}$}} & \multicolumn{2}{|c|}{ Sugar beet pulp } & \multicolumn{2}{|c|}{ Orange peel } & \multirow{2}{*}{0.27} \\
\hline & & & & & & & & \\
\hline \multicolumn{8}{|c|}{ pH value } & \multirow{3}{*}{0.36} \\
\hline 3 & 4 & 5 & 6 & \multicolumn{2}{|c|}{7} & \multicolumn{2}{|c|}{8} & \\
\hline $27.01^{\mathrm{b}}$ & $28.44^{\mathrm{a}}$ & $26.18^{c}$ & $25.7^{\mathrm{c}}$ & \multicolumn{2}{|c|}{$25.72^{\mathrm{c}}$} & \multicolumn{2}{|c|}{$24.7^{\mathrm{d}}$} & \\
\hline \multicolumn{8}{|c|}{ Concentration of pomegranate peel (\%) } & \multirow{3}{*}{1.002} \\
\hline 2.5 & 5 & 7.5 & 10 & 12.5 & 15 & $\mathbf{1 7 . 5}$ & 20 & \\
\hline $15.49^{\mathrm{e}}$ & $17^{\mathrm{e}}$ & $20.9^{\mathrm{d}}$ & $22.33^{\mathrm{d}}$ & $25.4^{\mathrm{c}}$ & $29.53^{\mathrm{a}}$ & $27.57^{a b}$ & $26.36^{\mathrm{bc}}$ & \\
\hline \multicolumn{8}{|c|}{ incubation period (day) } & \multirow{3}{*}{0.442} \\
\hline $\mathbf{1}$ & 2 & 3 & 4 & 5 & 6 & \multicolumn{2}{|c|}{7} & \\
\hline $26.6^{\mathrm{d}}$ & $29.53^{b}$ & $31.55^{\mathrm{a}}$ & $29.57^{\mathrm{b}}$ & $29.18^{\mathrm{bc}}$ & $28.52^{\mathrm{c}}$ & \multicolumn{2}{|c|}{$26.94^{\mathrm{d}}$} & \\
\hline \multicolumn{8}{|c|}{ Nitrogen sources } & \multirow{3}{*}{0.47} \\
\hline \multirow{2}{*}{\multicolumn{2}{|c|}{$\frac{(\mathbf{N H 4})_{2} \mathbf{S O}_{4}}{29.82^{c}}$}} & \multirow{2}{*}{\multicolumn{2}{|c|}{$\begin{array}{l}\mathrm{NH}_{4} \mathrm{Cl} \\
2171^{\mathrm{b}}\end{array}$}} & \multicolumn{2}{|c|}{ Yeast extract } & Peptone & Urea & \\
\hline & & & & \multicolumn{2}{|c|}{$33.97^{a}$} & $31.21^{b c}$ & $31.82^{b}$ & \\
\hline
\end{tabular}

Average in the same row having different superscripts are differ significantly $(\mathrm{P}<0.05)$ for $a, b, c, d$ and e.

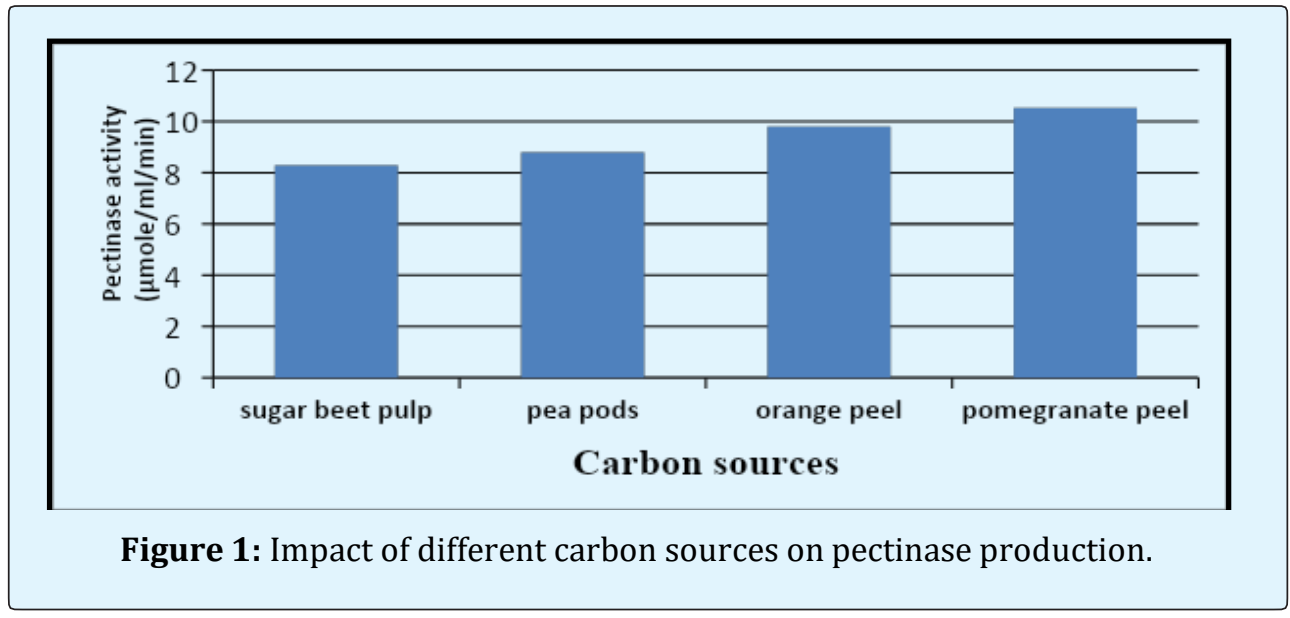




\section{Effect of Different Carbon Sources on Pectinase Production}

It is generally agreed that the optimum medium for the enhanced production of pectinase is that containing pectic materials as an inducer [28-30]. The selection of a suitable substrate for the fermentation process is a critical factor. As shown in Table 2 and Figure 1 Pomegranate peel as pectolytic substrate increased significantly $(\mathrm{P}<0.05)$ pectinase activity by Penicillium chrysogenum reached (10.53 $\mu \mathrm{mole} / \mathrm{ml} / \mathrm{min})$, while sugar beet pulp gave the lowest pectinase activity (8.29 $\mu \mathrm{mole} / \mathrm{ml} / \mathrm{min}$ ). From the previous data, pomegranate peel selected as a sole carbon source for conducting further studies on pectinase production by Penicillium chrysogenum.

\section{Effect of Carbon Source Concentration on Pectinase Production}

Data illustrated in Table 2 and Figure 2 showed effect of different concentration of pomegranate peel powder ranged from $2.5 \%$ to $20 \%$ (W/V) on pectinase production by Penicillium chrysogenum. Maximum pectinase activity $(\mathrm{P}<0.05)$ reached $(29.53 \mu \mathrm{mole} / \mathrm{ml} / \mathrm{min})$ was obtained at $15 \%(\mathrm{w} / \mathrm{v})$ pomegranate peel powder concentration, while the minimum activity reached (15.49 $\mu$ mole $/ \mathrm{ml} / \mathrm{min}$ ) was obtained at $2.5 \%$ of pomegranate peel powder concentration of Penicillium chrysogenum growth medium. This result is in line with that obtained by Castilho, et al. [31] who found that pectinase formation by $A$. niger decreases at high moisture levels. Moisture content is a critical factor on enzymes production processes because this variable has influence on growth and biosynthesis and secretion of different metabolites $[32,33]$. Higher moisture levels (as $2.5 \%$ pomegranate peel powder concentration can cause a reduction in enzyme yield due to steric hindrance of the growth of the producer strain by reduction in porosity (interparticle spaces) of the solid matrix, thus interfering oxygen transfer [34]. On the other hand, Mamma, et al. [35] reported that lower moisture content causes reduction in solubility of nutrients of the substrate, low degree of swelling and high water tension. In addition, Acuna Arguelles, et al. [36] reported that, in media with low water-availability fungi suffer modifications in their cell membrane, leading to transport limitations and affecting microbial metabolism. This may be the reason for reduction of pectinase enzyme activity at 17.5 and $20 \%$ of pomegranate peel powder concentration of fungal growth medium. Based on these data, pomegranate peel powder concentration at $15 \%(\mathrm{w} / \mathrm{v})$ was chosen for further studies.

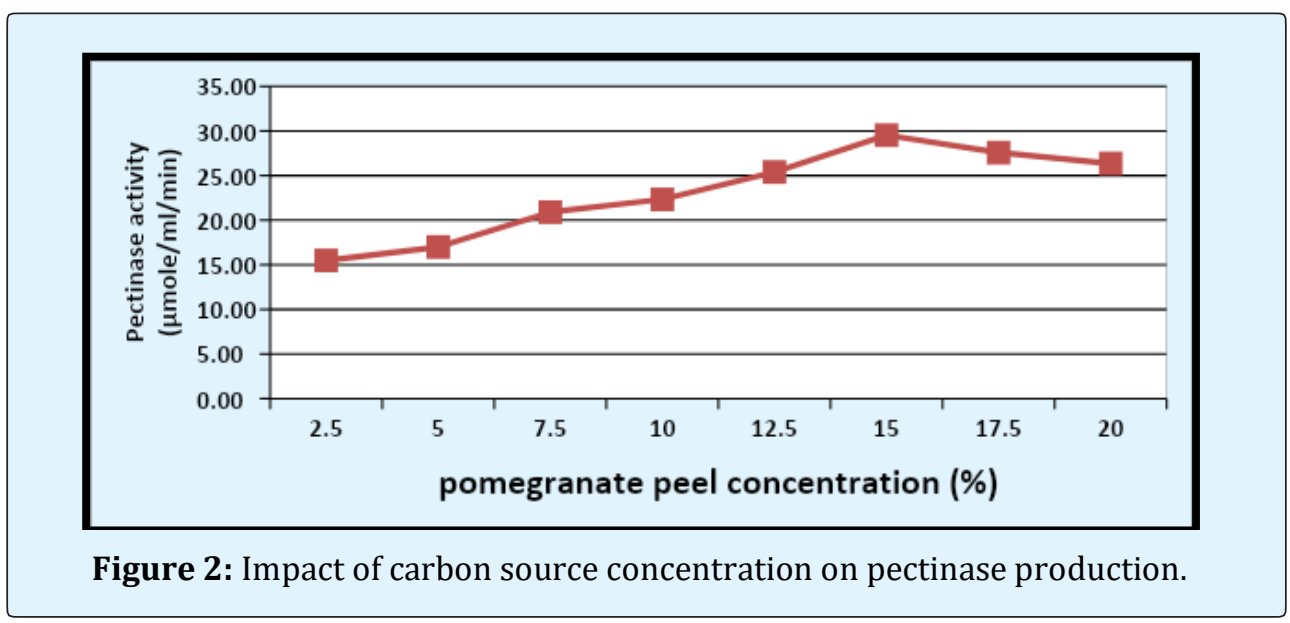

\section{Effect of Initial pH of Fungal Growth Medium on Pectinase Production}

As shown in Table 2 and Figure 3 initial $\mathrm{pH}$ of the medium has profound effect on pectinase production. Pectinase production by Penicillium chrysogenum grown on deferent $\mathrm{pH}$ values of pomegranate peel powder showed its highest values $(\mathrm{P}<0.05)$ reached $(28.44$ $\mu \mathrm{mole} / \mathrm{ml} / \mathrm{min}$ ), at $\mathrm{pH} 4.0$. According to Dalagnol, et al.
[37] extreme $\mathrm{pH}$ values may change the protein structure, leading to a partial or irreversible denaturation, resulting in a loss of activity. Moreover when the $\mathrm{pH}$ level increased, the enzyme production decreased. The initial $\mathrm{pH}$ of the medium has a great effect on the growth of the organism, permeability membrane, as well as on the biosynthesis and stability of the enzymes [38,39]. Optimum production of pectic enzymes from many molds 
within the acidic $\mathrm{pH}$ range has been reported by previous studies [37,40-42]. While, Debing, et al. [43] found that the $\mathrm{pH} 6.5$ was the optimal $\mathrm{pH}$ for pectinase production from A. niger by solid state fermentation. Also, Rasheedha, et al. [44] found that P. chrysogenum exhibited maximum polygalacturonase production at initial $\mathrm{pH}$ of 6.5 . Based on the obtained results, the initial $\mathrm{pH}$ of the medium was adjusted to $\mathrm{pH} 4.0$ in subsequent experiments.

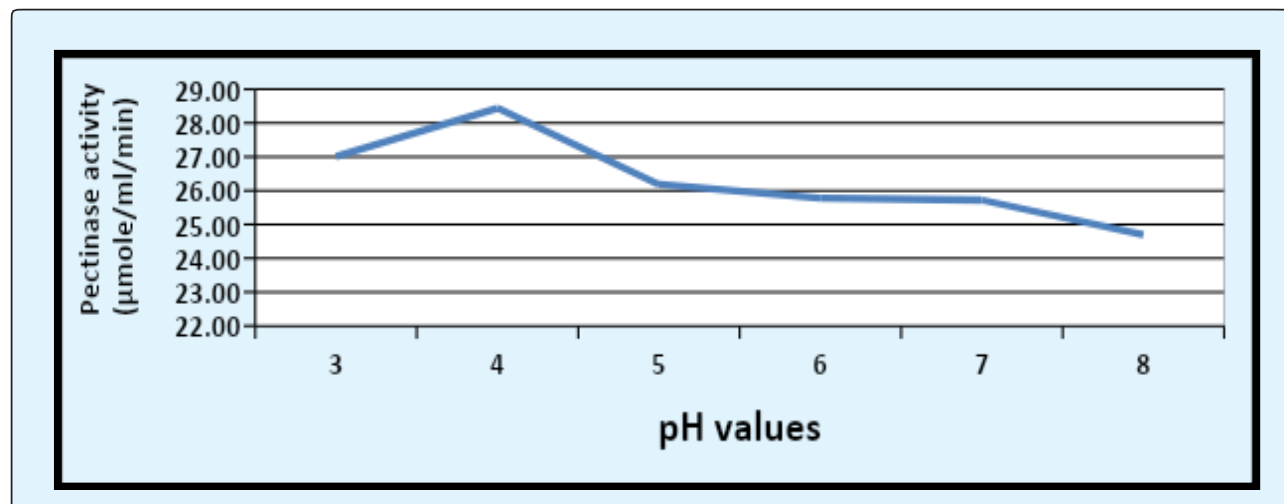

Figure 3: Effect of initial pH of fungal growth medium on pectinase production.

\section{Effect of Incubation Period on Pectinase Production}

Production of pectinase was monitored for a period of seven days as shown in Table 2 and Figure 4. The highest pectinase activity $(\mathrm{P}<0.05) \quad$ reached $\quad(31.55$ $\mu \mathrm{mole} / \mathrm{ml} / \mathrm{min}$ ) was recorded after three days of incubation with Penicillium chrysogenum. In addition, when the incubation period increased, the enzyme production decreased. The time of incubation depends on the growth rate of the microorganism and its enzyme production pattern. Ghildyal, et al. [45] investigated that, maximum production of pectic enzyme from different molds varies from 1 to 6 days. Castilho, et al. [31] reported that, highest pectinase activity was obtained by
A. niger, for fermentation time $22 \mathrm{~h}$ while, Rangarajan, et al. [46] found that, pectinase show maximum activity after $40 \mathrm{~h}$ of fermentation by A. niger grow on orange peel. In addition, Leda, et al. [47] reported that, the highest polygalacturonase activities were obtained by A. niger after $70 \mathrm{~h}$ of fermentation period. Moreover, Sarvamangala, et al. [48] observed a gradual increase in the production of pectinase from deseeded sunflower head by $A$. niger after $72 \mathrm{~h}$ of fermentation period in submerged and up to $96 \mathrm{~h}$ in solid-state conditions. From the previous data, 3 days incubation period was selected for conducting further studies on modified pomegranate peel powder medium.

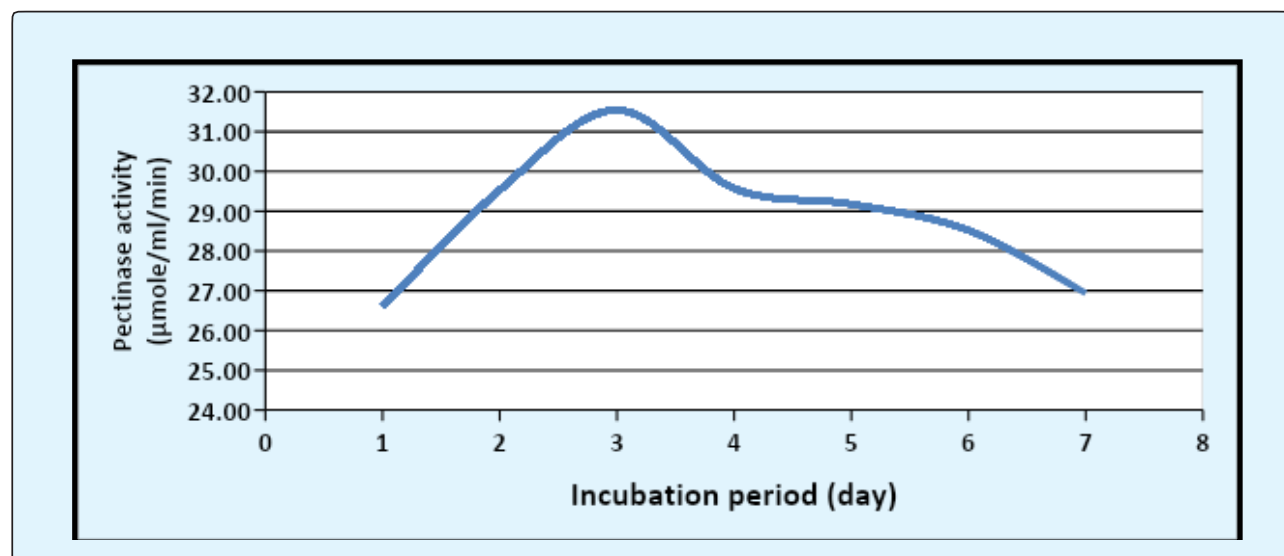

Figure 4: Effect of incubation period on pectinase production. 


\section{International Journal of Zoology and Animal Biology}

\section{Effect of Nitrogen Sources on Pectinase Production}

The effects of organic and inorganic nitrogen sources on the production of pectinase were extensively studied [49-51]. Data of Table 2 and Figure 5 showed that, among five nitrogen sources tested for screening their effect on pectinase production. Yeast extract was found to be the best nitrogen source producing the highest level $(\mathrm{P}<0.05)$ of pectinase activity $(33.97 \mu \mathrm{mole} / \mathrm{ml} / \mathrm{min})$ by Penicillium chrysogenum. These data indicating that the source of nitrogen should be organic for the best level of pectinase production. Our results are in line with the work of Azzaz, et al. [6] who stated that, yeast extract was found to be the best nitrogen source for pectinase production by A. niger
(3.78 U/ml) on beet pulp powder media. Also, Aguilar, et al. [49] who reported that yeast extract the best inducer of pectinases by Aspergillus sp. Moreover, Kashyap, et al. [50] found that, yeast extract, peptone and ammonium chloride were found to enhance pectinase production up to $24 \%$ and addition of glycine, urea and ammonium nitrate inhibited pectinase production. In addition, Vivek, et al. [51] found that, organic nitrogen sources showed higher endo, exo pectinases activities than inorganic nitrogen sources. Also the increasing trend in the enzymes activity with the increase in nitrogen source content was observed in the case of organic nitrogen sources while decreasing trend observed for inorganic nitrogen sources.

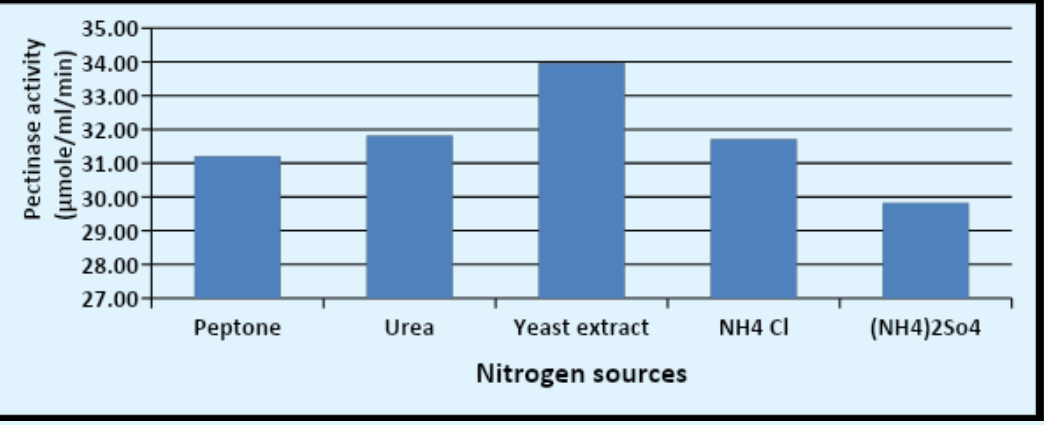

Figure 5: Effect of nitrogen sources on pectinase production.

\section{In Vitro DMD, NDF and ADF Degradation of the Tested Rations}

Results of Table 3 showed that, all the produced enzyme and SMIZYME ${ }^{\circledR}$ supplementation levels increased $(\mathrm{P}<0.05)$ the in vitro DMD, NDF and ADF degradation for the tested rations compared to control one. Increasing the produced enzyme and SMIZYME ${ }^{\circledR}$ supplementation levels up to $3 \mathrm{~g} / \mathrm{kg}$ DM gave the highest values of in vitro DMD degradation.

Table 3: Fibrolytic enzymes effect on DMD, NDF and ADF degradation of the tested rations (in vitro).

\begin{tabular}{|c|c|c|c|c|c|c|c|}
\hline Enzymes Source & Enzyme level g/Kg DM & IVDMD\% & $\mathbf{\pm S E}$ & $\mathbf{I V N D F} \%$ & $\mathbf{\pm S E}$ & $\mathbf{I V A D F} \%$ & $\mathbf{\pm S E}$ \\
\hline Control & 0 & $45.16^{\mathrm{e}}$ & 0.58 & $26.74^{\mathrm{d}}$ & 0.6 & $20.22^{\mathrm{f}}$ & 0.19 \\
\hline \multirow{4}{*}{ The produced enzyme } & 1 & $47.45^{\mathrm{d}}$ & 0.55 & $30.39^{\mathrm{cd}}$ & 2.68 & $23.19^{\mathrm{d}}$ & 0.97 \\
\cline { 2 - 8 } & 2 & $48.8^{\mathrm{bc}}$ & 0.03 & $36.22^{\mathrm{a}}$ & 0.38 & $28.72^{\mathrm{ab}}$ & 0.61 \\
\cline { 2 - 8 } & 3 & $51.68^{\mathrm{a}}$ & 0.56 & $37.39^{\mathrm{a}}$ & 0.32 & $29.46^{\mathrm{ab}}$ & 0.15 \\
\cline { 2 - 8 } & 4 & $49.76^{\mathrm{b}}$ & 0.59 & $35.51^{\mathrm{a}}$ & 0.43 & $28.00^{\mathrm{bc}}$ & 0.68 \\
\hline \multirow{4}{*}{ SMIZYME $^{\circledR}$} & 5 & $49.10^{\mathrm{bc}}$ & 0.09 & $34.45^{\mathrm{ab}}$ & 0.37 & $26.97^{\mathrm{c}}$ & 0.15 \\
\cline { 2 - 8 } & 1 & $48.22^{\mathrm{cd}}$ & 0.3 & $28.68^{\mathrm{cd}}$ & 2.07 & $20.84^{\mathrm{ef}}$ & 0.13 \\
\cline { 2 - 8 } & 2 & $52.31^{\mathrm{cd}}$ & 0.24 & $31.40^{\mathrm{bc}}$ & 1.45 & $22.11^{\mathrm{de}}$ & 0.01 \\
\cline { 2 - 8 } & 3 & 0.35 & $34.42^{\mathrm{ab}}$ & 0.08 & $29.90^{\mathrm{a}}$ & 0.09 \\
\cline { 2 - 8 } & $41.59^{\mathrm{a}}$ & 0.12 & $38.19^{\mathrm{a}}$ & 1.03 & $29.71^{\mathrm{a}}$ & 0.29 \\
\cline { 2 - 8 } & 4 & $49.95^{\mathrm{b}}$ & 0.2 & $38.12^{\mathrm{a}}$ & 0.04 & $29.06^{\mathrm{ab}}$ & 0.53 \\
\hline
\end{tabular}

Average in the same column having different superscripts are differ significantly $(\mathrm{P}<0.05)$ for $a, b, c d, e$ and $f$. 
Colombatto, et al. [52] mentioned that, using commercial enzyme product supplemented to alfalfa stems at six levels: $0,0.51,1.02,2.55,5.1$ and $25.5 \mathrm{~g} / \mathrm{kg}$ $\mathrm{DM}$, increased in vitro DM, NDF, ADF, and hemicellulose degradation compared to control. Also Pinos, et al. [53] showed that, enzymes improved ruminal disappearance rates of DM and NDF in situ of total mixed ration (TMR) with three different forage: concentrate ratios (400:600, $500: 500,600: 400 \mathrm{~g} / \mathrm{g}$ ) and two (0 or $2 \mathrm{~g}$ ) levels of enzymes/kg DM. Moreover Azzaz, et al. [54] investigated that Asperozym and Bacillozym ${ }^{\circledR}$ addition to banana wastes increased IVDMD and IVOMD significantly compared with the untreated banana wastes (Control). From the result of the current study, increasing of DM, NDF, ADF, and hemicellulose degradation (in vitro) because of supplemented rations with fibrolytic enzymes may be increased numbers of total bacteria and Fibrobacter succinogens in the incubation medium with improving in vitro fermentation as mentioned by Mao, et al. [55]. Moreover Kholif, et al. [56] found that, the treatment with commercial cellulolytic enzymes (Veta-
Zyme Plus ${ }^{\circledR}$ ) increased DM digestibility (in vitro) further Aboul Fotouh, et al. [4] reported that, addition lactating goats with Asperozym and Phytabex plus ${ }^{\circledR}$ at levels up to 1000 unit of cellulolytic enzymes/kg DM increase $(\mathrm{P} \leq 0.05)$ values of IVDMD compared to control.

\section{In Vitro PH Value, TGP, NH3-N and SCFA of the Tested Rations}

Data of Table 4 showed that, all the produced enzyme and SMIZYME ${ }^{\circledR}$ supplemented levels decreased $(\mathrm{P}<0.05)$ in vitro $\mathrm{pH}$ value and increased $(\mathrm{P}<0.05)$ total gas production (TGP) compared to control ration. The highest values $(\mathrm{P}<0.05)$ of in vitro $\mathrm{pH}(6.7)$ was recorded by control ration, while the ration supplemented with SMIZYME ${ }^{\circledR}$ recorded the lowest values of in vitro $\mathrm{pH}$ (5.69) at levels up to $3 \mathrm{~g} / \mathrm{kg}$ DM .On the other hand, the highest values of in vitro TGP was recorded by the produced enzyme ration reached (295.26) at levels up to $4 \mathrm{~g}$ enzyme /kg DM., while control ration recorded the lowest values of in vitro TGP reached (283.66).

Table 4: Fibrolytic enzymes effect on $\mathrm{pH}$ value andTGP of the tested rations (in vitro).

\begin{tabular}{|c|c|c|c|c|c|}
\hline Enzymes Source & Enzyme level g/Kg DM & $\mathbf{p H}$ value & $\mathbf{\pm S E}$ & $\mathbf{T G P} / \mathbf{1 g}$ & $\mathbf{\pm S E}$ \\
\hline Control & 0 & $6.70^{\mathrm{a}}$ & 0.14 & $283.66^{\mathrm{d}}$ & 0.6 \\
\hline \multirow{4}{*}{$\begin{array}{c}\text { The produced } \\
\text { enzyme }\end{array}$} & 1 & $6.47^{\mathrm{b}}$ & 0.03 & $290.05^{\mathrm{bc}}$ & 0.93 \\
\cline { 2 - 6 } & 2 & $6.37^{\mathrm{bc}}$ & 0.05 & $291.62^{\mathrm{b}}$ & 0.44 \\
\cline { 2 - 6 } & 3 & $6.15^{\mathrm{d}}$ & 0.06 & $294.99^{\mathrm{a}}$ & 0.08 \\
\cline { 2 - 6 } & 4 & $6.24^{\mathrm{cd}}$ & 0.01 & $295.26^{\mathrm{a}}$ & 0.11 \\
\cline { 2 - 6 } & 5 & $6.38^{\mathrm{bc}}$ & 0.06 & $294.45^{\mathrm{a}}$ & 1.01 \\
\cline { 2 - 6 } & $6.13^{\mathrm{d}}$ & 0.12 & $291.37^{\mathrm{b}}$ & 1.32 \\
\cline { 2 - 6 } & 2 & $5.89^{\mathrm{e}}$ & 0.01 & $295.02^{\mathrm{a}}$ & 0.73 \\
\cline { 2 - 6 } & 3 & $5.69^{\mathrm{e}}$ & 0.1 & $294.44^{\mathrm{a}}$ & 1.04 \\
\cline { 2 - 6 } & 4 & $5.74^{\mathrm{e}}$ & 0.07 & $288.07^{\mathrm{c}}$ & 0.18 \\
\cline { 2 - 6 } & 5 & $5.87^{\mathrm{e}}$ & 0.01 & $287.66^{\mathrm{c}}$ & 1.3 \\
\hline
\end{tabular}

Average in the same column having different superscripts are differ significantly $(\mathrm{P}<0.05)$ for $a, b, c, d$ and e.

No significantly difference was found among control and fibrolytic enzymes ration of in vitro NH3-N as reported in Table 5. Control ration recorded the highest value of in vitro $\mathrm{NH} 3-\mathrm{N}$, being $(2.78 \mu \mathrm{mol} / \mathrm{ml})$, while the lowest in vitro $\mathrm{NH} 3-\mathrm{N}$, being $(2.03 \mu \mathrm{mol} / \mathrm{ml})$ recorded by ration supplemented with SMIZYME $^{\circledR}$ at levels up to $1 \mathrm{~g} / \mathrm{kg}$ DM.

Moreover data of Table 5 showed that, all the produced enzyme and SMIZYME ${ }^{\circledR}$ supplementation levels increased $(\mathrm{P}<0.05)$ the in vitro short chain fatty acid (SCFA). Control ration recorded the lowest value of in vitro short chain fatty acid (SCFA) being $(1.255 \mathrm{mmol} / \mathrm{dl})$, while the highest value in vitro SCFA, being $(1.310$ $\mathrm{mmol} / \mathrm{dl}$ ) recorded by ration supplemented with the produced enzyme at levels up to 3-4 g per $\mathrm{kg}$ DM. Through the previous data, the increase of DM, NDF ADF degradation plus to increase production of TGP and SCFA of rations supplemented with fibrolytic enzymes may be due to increasing digestion and improving ruminal fermentation as mentioned by Nsereko, et al. [57]. Also Mohamed, et al. [58] found that, after $24 \mathrm{hr}$. of incubation, all enzymatic treatment decrease final $\mathrm{pH}$, increased dry matter (DM), neutral detergent fiber (NDF) and acid detergent fiber (ADF) digestibility of substrate. Also, acetate and propionate productions were increased by all enzymatic treatments. Further Giraldo, et al. [59] indicated that, adding fibrolytic enzymes enhanced in 
vitro fermentation by increasing substrate fiber degradation, Volatile Fatty Acids (VFA) production, and ruminal microbial growth. Moreover Elghandour, et al. [60] obtained decreased ruminal $\mathrm{pH}$ values and increased in vitro SCFA production when incubated 4 fibrous feeds, including corn stover, with different levels of exogenous fibrolytic enzyme. The effectiveness of enzymes depends upon substrate, enzyme specificity and enzyme dose causing variable responses with different enzyme preparations and doses [61]. Increased TGP indicated the increased fermentable material with enzyme addition [62]. Also Vallejo, et al. [63] investigate that, addition of cellulase and xylanase linearly decreased $(\mathrm{P} \leq 0.05) \mathrm{pH}$ compared to control, this may be due to greater enzymatic hydrolysis of feeds into readily fermentable substrates that depress $\mathrm{pH}$ when fermented. Further Handique, et al. [64] reported that, the in vitro study by using complete feed containing bajra straw supplemented with exogenous fibrolytic enzyme increase in total volatile fatty acid and an unaltered rumen $\mathrm{pH}$, total nitrogen and ammonia $\mathrm{N}$ compared to control. These support the hypothesis that a suitable enzyme dose could improve fermentation efficiency $[65,66]$.

Table 5: Fibrolytic enzymes effect on $\mathrm{NH}_{3}-\mathrm{N}$ and SCFA of the tested rations (in vitro).

\begin{tabular}{|c|c|c|c|c|c|}
\hline Enzymes Source & Enzyme level g/Kg DM & $\mathbf{N H 3 - N ~} \boldsymbol{\mu m o l} / \mathbf{m l}$ & $\mathbf{\pm S E}$ & $\mathbf{S C F A}(\mathbf{m m o l} / \mathbf{d l})$ & $\mathbf{\pm S E}$ \\
\hline Control & 0 & 2.78 & 0.09 & $1.255^{\mathrm{d}}$ & 0.005 \\
\hline \multirow{4}{*}{ The produced enzyme } & 1 & 2.75 & 0.2 & $1.284^{\mathrm{c}}$ & 0.005 \\
\cline { 2 - 6 } & 2 & 2.59 & 0.12 & $1.291^{\mathrm{bc}}$ & 0.001 \\
\cline { 2 - 6 } & 3 & 2.4 & 0.02 & $1.306^{\mathrm{a}}$ & 0.005 \\
\cline { 2 - 6 } & 4 & 2.66 & 0.07 & $1.307^{\mathrm{a}}$ & 0.003 \\
\cline { 2 - 6 } & 5 & 2.56 & 0.23 & $1.303^{\mathrm{ab}}$ & 0.004 \\
\hline \multirow{4}{*}{ SMIZYME® } & 1 & 2.03 & 0.21 & $1.289^{\mathrm{bc}}$ & 0.01 \\
\cline { 2 - 6 } & 2 & 2.6 & 0.32 & $1.306^{\mathrm{ab}}$ & 0.006 \\
\cline { 2 - 6 } & 3 & 2.29 & 0.51 & $1.303^{\mathrm{ab}}$ & 0.005 \\
\cline { 2 - 6 } & 4 & 2.33 & 0.14 & $1.275^{\mathrm{c}}$ & 0.004 \\
\cline { 2 - 6 } & 5 & 2.77 & 0.08 & $1.273^{\mathrm{c}}$ & 0.0039 \\
\hline
\end{tabular}

Average in the same column having different superscripts are differ significantly $(\mathrm{P}<0.05)$ for $a, b, c$ and $d$.

\section{Conclusion}

Fungal pectinase enzyme was locally produced (the produced enzyme) under the optimum conditions. This would contribute for reducing the cost of importation. The evaluated fibrolytic enzymes (the produced enzyme and SMIZYME ${ }^{\circledR}$ ) were increased DM, NDF, ADF, TGP and SCFA (in vitro).

\section{References}

1. Murad HA, Azzaz HH (2011) Microbial pectinases and ruminant nutrition. Research journal of microbiology 6(3): 246-269.

2. Ruiz HA, Rodrigue Jasso R, Rodriguez R, Contreras Esquivel JC, Aguilar CN (2012) Pectinase production from lemon peel pomace as support and carbon source in solid-state fermentation column-tray bioreactor. Biochem Eng J 65: 90-95.

3. El Enshasy HA, Elsayed EA, Suhaimi N, Abd Malek R, Esawy M (2018) Bioprocess optimization for pectinase production using Aspergillus niger in a submerged cultivation system. BMC Biotechnology 18: 71 .

4. Aboul Fotouh GE, El Garhy GM, Azzaz HH, Abd El Mola AM, Mousa G A (2016) Fungal cellulase production optimization and its utilization in goat's rations degradation. Asian Journal of Animal and Veterinary Advances Journal 11(12): 824-831.

5. Khattab MS, Azzaz HH, Abd El Tawab AM, Murad H A ( 2019) Production optimization of fungal cellulase and its impact on ruminal degradability and fermentation of diet. Int J Dairy Sci 14(2): 61-68.

6. Azzaz HH, Murad HA, Kholif AM, Morsy TA, Mansour AM, et al. (2013a) Pectinase production optimization and its application in panama fiber degradation. Egyptian J Nutrition and Feeds 16(2): 117-125.

7. Murad HA, Azzaz HH (2010) Cellulase and dairy animal feeding. Biotechnology 9(3): 238-256.

8. Azzaz HH, Murad HA, Kholif AM, Hanfy MA, Abdel Gawad MH (2012) Optimization of Culture Conditions 
Affecting Fungal Cellulase Production. Research Journal of Microbiology 7(1): 23-31.

9. Azzaz HH, Morsy TA, Murad HA (2016) Microbial Feed Supplements for Ruminant's Performance Enhancement. Asian Journal of Agricultural Research 10(1): 1-14.

10. Azzaz HH, Murad HA, Kholif AM, Morsy TA, Mansour $A M$, et al. (2013) Increasing nutrients bioavailability by using fibrolytic enzymes in dairy buffaloes feeding. Journal of Biological Sciences 13(4): 234-241.

11. Azzaz HH, Eman SA Farahat, Ebeid HM (2017) Effect of partial replacement of corn grains by date seeds on rahmani ram's nutrients digestibility and Nubian goat's milk production. Int J Dairy Sci 12(4): 266-274.

12. Kholif AE, Kassab AY, Azzaz HH, Matloup OH, Hamdon HA, et al. (2018) Essential oils blend with a newly developed enzyme cocktail works synergistically to enhance feed utilization and milk production of Farafra ewes in the subtropics. Small Ruminant Research 161: 43-50.

13. Buga ML, Ibrahim S, Nok AJ (2010) Partially purified polygalacturonase from Aspergillus niger (SA6). African Journal of Biotechnology 9(52): 8944-8954.

14. Mandels M, Hontz L, Nystrom J (1974) Enzymatic hydrolysis of waste cellulose. Biotech Bioeng 16: 1471.

15. Soares MN, Silva R, Gomes E (1999) Screening of Bacterial Strains for Pectinolytic Activity Characterization of the pgase Produced by Bacillus species. Rev Microbiol 30: 229-303.

16. Miller GL (1972) Use of dinitrosalicyclic acid reagent for determination of reducing sugar. Biotechnol Bioeng Symp 5: 193-219.

17. Ismail SA, Abdel Fattah AM, Emran MA, Azzaz HH, El Gamal MS, et al. (2018) Effect of Partial Substitution of Ration's Soybean Meal by Biologically Treated Feathers on Rumen Fermentation Characteristics (in vitro). Pakistan Journal of Biological Sciences 21: 110118.

18. Navarro Villa A, M O'brien, Lopez S, Boland TM, O'kiely P (2011) Modifications of a gas production technique for assessing in vitro rumen methane production from feedstuffs. Anim Feed Sci Technol 166-167: 163-174.
19. Szczechowiak J, Szumacher Strabel M, El Sherbiny ME, Pers Kamczyc P, Pawlak, et al. (2016) Rumen fermentation, methane concentration and fatty acid proportion in the rumen and milk of dairy cows fed condensed tannin and/or fish-soybean oils blend. Anim Feed Sci Technol 216: 93-107.

20. Makkar HP (2005) In vitro gas methods for evaluation of feeds containing phytochemicals. Anim Feed Sci Technol 123: 291-302.

21. IBM Corp Released (2011) IBM SPSS Statistics for Windows. Version 20.0. Armonk, NY: IBM Corp.

22. Duncan DB (1955) Multiple range and multiple F-test. Biometrics 11: 1-42.

23. Cao J, Zheng L, Chen S (1992) Screening of pectinase producer from alkalophilic bacteria and study on its potential application in degumming of ramie. Enzyme and Microbial Technology 14(12): 1013-1016.

24. Blanco P, Sieiro C, Villa TG (1999) Production of pectic enzymes in yeast. FEMS Microbiology Letters 175: 1-9.

25. Huang LK, Mahoney RR (1999) Purification and characterization of an endo-polygalacturonase from Verticillum alboatrum. Journal of Applied Microbiology 86(1): 145-146.

26. Godfrey T, West S (1996) Industrial Enzymology. $2^{\text {nd }}$ (Edn.), London: Macmillan Press.

27. Uhlig H (1998) Industrial enzymes and their applications, New York: John Wiley \& Sons, Inc pp: 435.

28. Solis Pereira S, Favela Torres E, Viniegra Gonzales G, Gutierrz-Rojas M (1993) Effect of different carbons sources on the synthesis of pectinase by Aspergillus niger in submerged and solid state fermentation. Appl Microbiol Biotechnol 39: 36-41.

29. Hang YD, Woodanms EE (1994) Production of fungal polygalacturonase from apple pomace. Lebensm. Wiss U Technol 27: 194-196.

30. Naidu GSN, Pandam T (1998) Production of pectolytic enzymes a review Process Eng 19(5): 355-361.

31. Castilho LR, Ricardo AM, Tito LMA (2000) Production and extraction of pectinases obtained by solid state 


\section{International Journal of Zoology and Animal Biology}

fermentation of agroindustrial residues with Aspergillus niger. Bioresource Technol 71: 45-50.

32. Krishna C, Chandrasekaran M (1996) Banana waste as substrate for aamylase production by Bacillus subtilis (CBTK 106) under solid state fermentation. Appl Microbiol Biotechnol 46(2): 106-111.

33. Ellaiah PK, Adinarayana Y, Bhavani P, Padmaja B, Srinivasulu (2002) Optimization of process parameters for glucoamylase production under solid state fermentation by a newly isolated Aspergillus species. Process Biochem 38(4): 615-620.

34. Lonsane BK, Ghildyal NP, Budiatman S, Ramakrishna SV (1985) Engineering aspects of solid state fermentation. Enzyme Microbiol Technol 7(6): 258265.

35. Mamma D, Kourtoglou E, Christakopoulos P (2008) Fungal multienzyme production on industrial byproducts of the citrus-processing industry. Bioresource Technolo 99(7): 2373-2383.

36. Acuna Arguelles ME, Guti_errez Rojas M, Viniegra Gonz_alez G, Favela-Torres E (1995) Production and properties of three pectinolytic activities produced by A. niger in submerged and solid state fermentations. Appl Microbio, Biotechnol 43(5): 808-814.

37. Dalagnola LMG, Silveiraa VCC, Silvaa HBD, Manfroib V, Rodrigues RC (2017) Improvement of pectinase, xylanase and cellulase activities by ultrasound: Effects on enzymes and substrates, kinetics and thermodynamic parameters. Process Biochemistry 61: 80-87.

38. Shoichi T, Xoighi K, Hiroshi S (1985) Cellulase production by P. purpurogenum. J Ferment Technol 62: 127

39. Poorna AC, Prema P (2006) Production of cellulase free endoxylanase from novel alkalophilic thermotolerent Bacillus pumillus by solid state fermentation and its application in wastepaper recycling. Bio Reso Tech 98(3): 485-490.

40. Zetelaki Horvath K (1980) Factors affecting pectinase activity. Acta Alimentaria 10: 371-378.

41. Shin I, Dowmez S, Kilic O (1983) Study on pectolytic enzyme production from some agricultural wastes by fungi. Chemical Microbiologie Technologie der Lebensm 8: 87-90.
42. Ma X, Wang D, Yin M, Lucente J, Wang W, et al. (2017) Characteristics of pectinase treated with ultrasound both during and after the immobilization process, Ultrason Sonochem 36: 1-10.

43. Debing J, Peizun L, Stagnitti F, Xianzhe X, Li L (2006) Pectinase production by solid fermentation from Aspergillus niger by a new prescription experiment. Ectoxicology and Environ 64(2): 244-250.

44. Rasheedha AB, Kalpana MD, Gnanaprabhal GR, Pradeep BV, Palaniswamy M (2010) Production and characterization of pectinase enzyme from Penicillium chrysogenum 3(4): 377-381.

45. Ghildyal NP, Ramakrishna SV, Nirmala P, Devi BK, Asthana HA (1981) Large scale production of pectolytic enzyme by solid state fermentation. Journal of Food Science and Technology 18(6): 243-251.

46. Rangarajan V, Rajasekharan M, Ravichandran R, Sriganesh K, Vaitheeswaran V (2010) Pectinase Production from Orange Peel Extract and Dried Orange Peel Solid as Substrates Using Aspergillus niger. International Journal of Biotechnology and Biochemistry 6: 445-453.

47. Leda RC, Ricardo AM, Tito LM (2000) Production and extraction of pectinases obtained by solid state fermentation of agroindustrial residues with Aspergillus niger. Bioresource Technology 71: 45-50.

48. Sarvamangala RP, Dayanand A (2006) Production of pectinase from deseeded sunflower head by Aspergillus niger in submerged and solid-state conditions. Bioresource Technology 97(16): 20542058.

49. Aguilar G, Trejo B, Garcia J Huitron G (1991) Influence of $\mathrm{pH}$ on endo and exo- pectinase production by Aspergillus species CH-Y-1043. Can J Microbiol 37: 912-917.

50. Kashyap DR, Soni SK, Tewari R (2003) Enhanced production of pectinase by Bacillus sp. DT7 using solid state fermentation. Bioresou. Technol 88(3): 251-254.

51. Vivek R, Rajasekharan M, Ravichandran R, Sriganesh K, Vaitheeswaran V (2010) Pectinase production from orange peel extract and dried orange peel solid as substrates using Aspergillus niger. International Journal of Biotechnology and Biochemistry 6: 445453. 


\section{International Journal of Zoology and Animal Biology}

52. Colombatto D, Mould FL, Bhat MK, Owen E (2007) Influence of exogenous fibrolytic enzyme level and incubation $\mathrm{pH}$ on the in vitro ruminal fermentation of alfalfa stems. Anim Feed Sci Technol 137(1-2): 150162.

53. Pinos RJ, Moreno R, Gonzalez SS, Robinson PH, Mendoza G Alvarez G (2008) Effects of exogenous fibrolytic enzymes on ruminal fermentation and digestibility of total mixed rations fed to lambs. Anim Feed Sci Technol 142(3-4): 201-219.

54. Azzaz HH , Murad HA, Kholif AM, Hanafy MA, Abdel Gawad M H (2012b) Utilization of cellulolytic enzymes to improve the nutritive value of banana wastes and performance of lactating goats. Asian J Anim Vet Adv 7(8): 664-673.

55. Mao HL, Wu CH, Wang JK, Liu JX (2013) Synergistic effect of cellulase and xylanase on in vitro rumen fermentation and microbial population with rice straw as substrate. Animal Nutrition and Feed Technology 13: 477-487.

56. Kholif AM, Farahat ESA, Hanafy MA, Kholif SM, El Sayed RR (2015) Utilization of cellulolytic enzymes to improve the nutritive value of date kernels and the investigation of the impact of adding these enzymes to lactating goat's diets on rumen fermentation and nutrients digestibility. Asian J Anim Sci 9: 441-447.

57. Nsereko VL, Beauchemin KA, Morgavi DP, Rode LM , Furtado AF, et al. (2002) Effect of a fibrolytic enzyme preparation from Trichoderma longibrachiatum on the rumen microbial population of dairy cows. Can J Microbiol 48(1): 14-20.

58. Mohamed AM, El Saidy BE, Ibrahim K, Tejido ML, Carro MD (2005) Effect of exogenous enzymes on in vitro ruminal fermentation of a high-forage diet and productive response of lactating ewes. Egyptian J Nutr feeds 8: 591-602.

59. Giraldo LA, Tejido ML, Ranilla MJ, Carro MD (2008) Effects of exogenous fibrolytic enzymes on in vitro ruminal fermentation of substrates with different forage: concentrate ratios. Anim Feed Sci Technol 141: 306-325.

60. Elghandour MMY, Salem AZM, Gonzalez Ronquillo M, Brquez JL, Gado HM, et al. (2013) Effects of exogenous enzymes on in vitro gas production kinetics and ruminal fermentation of four fibrous feeds. Animal Feed Science and Technology 179(1-4): 46-53.

61. Salem AZM, Ammar H, Kholif AE, Elghandour MMY, Ortiz LB (2015) Effect of glucoamylase enzyme extract on in vitro gas production and degradability of two diets with $25 \%$ of corn or sorghum grains. Indian Journal of Animal Sciences 85: 183-188.

62. Elghandour MMY, Salem AZM, Martinez Castaneda JS, Camacho LM, Kholif AE, et al. (2015) Direct-fed microbes: A tool for improving the utilization of low quality roughages in ruminants. Journal of Integrative Agriculture 14(3): 526-533.

63. Vallejo LH, Salem AZM, Kholif AE, El Ghandour MMY, Fajardo RC, et al. (2016) Influence of cellulase or xylanase on the in vitro rumen gas production and fermentation of corn stover. Indian Journal of Animal Sciences 86 (1): 70-74.

64. Handique B, Maurya LK, Devi YR, Pearlin VB (2018) Supplementation of exogenous fibrolytic enzyme in livestock nutrition. Journal of Entomology and Zoology Studies 6(6): 302-305.

65. Azzaz HH, Murad HA, Morsy TA (2015) Utility of Ionophores for Ruminant Animals: A Review. Asian Journal of Animal Sciences 9(6): 254-265.

66. Abd El Tawab AM, Murad HA, Khattab MS, Azzaz HH (2019) Optimizing production of tannase and in vitro evaluation on ruminal fermentation, degradability and gas production. Int J Dairy Sci 14(2): 53-60. 